\title{
LinkedIn — portal społecznościowy dla profesjonalistów. Część II
}

\author{
Andrzej L. Komorowski
}

\section{LinkedIn — social media for professionals. Part II}

Nie wszyscy użytkownicy portalu Linkedln mają swoje profile w całości dostępne dla osób przeszukujących zawartość portalu. Szukając profli znajomego naukowca, możemy np. znaleźć jedynie jego imię z pierwszą literą nazwiska. Próby skontaktowania się z osobami chroniącymi częściowo swoją prywatność są również nieco utrudniane przez portal. Wynika to z tego, że twórcy Linkedln postawili sobie za cel umożliwienie dzielenia się jedynie tymi informacjami, które dana osoba życzy sobie udostępnić. Tworząc swój profil, możemy zatem nie umieszczać w nim pewnych informacji; alternatywnie można wykupić abonament pozwalający na korzystanie z bardziej zaawansowanej wersji profilu (za jej pomocą można udostępniać część informacji wszystkim, a wybranej grupie internautów - wszystkie dane). Dodatkowo abonament pozwala na zachowanie anonimowości podczas przeglądania innych profili. Standardowo w portalu Linkedln po przeglądnięciu profilu zawsze pozostaje ślad po odwiedzającym. Właściciel profilu dostanie informację, kto oglądał jego profil. Jednak jeśli gościem była osoba ze specjalnym abonamentem (a jednocześnie właściciel profilu odwiedzanego nie ma takiego abonamentu), to zostanie jedynie poinformowany, że jego profil oglądał „ktośz branży medycznej".

Zatem mamy już swój profil i wysłaliśmy do znajomych propozycję nawiązania kontaktu w obrębie portalu. Kiedy otrzymamy ich potwierdzenie i zbudujemy krąg znajomych, pojawia się pytanie: co dalej? W jaki sposób możemy wykorzystać fakt, że wszyscy jesteśmy użytkownikami portalu? Przecież do wysyłania listów do poszczególnych znajomych może służyć zwykła poczta albo poczta elektroniczna. Narzędziem, które w Linkedln może najbardziej się przydać, jest możliwość tworzenia i uczestniczenia w grupach dyskusyjnych. Grupy możemy wyszukiwać samodzielnie, może nam je sugerować sam portal, albo też możemy je po prostu stworzyć. Grupy mogą się zajmować jakimiś problemami, informować o działalności instytucji lub dotyczyć jakichś wydarzeń. Spójrzmy na grupy na profilu niżej podpisanego.
Grupy typu Asan Medical Center i Zurich University są grupami informującymi o bieżących wydarzeniach w uznanych ośrodkach medycznych odpowiednio w Seulu i Zurychu. Z kolei do członka grupy Surgeons Jobs spływają informacje o ciekawych propozycjach pracy na całym świecie. Grupy Hepato-Pancreato-Biliary Network oraz Liver Transplant są zaś typowymi grupami dyskusyjnymi. Aby obejrzeć zawartość większości grup trzeba się najpierw do nich zapisać. W tym celu należy — podczas pierwszych odwiedzin danej grupy — kliknąć odpowiednie pole na ekranie. Możemy to robić bez obawy: jeżeli grupa nam się nie spodoba, to wypisanie się z niej będzie równie proste jak zapisanie. Niektóre grupy chronią prywatność uczestników i wymienianych informacji, przyjmując jedynie zgłoszenie zainteresowania, a zezwalając na dostęp do ich wnętrza dopiero po weryfikacji nowego użytkownika. Do niektórych grup może nam się w ogóle nie udać zapisać, jeżeli są skierowane do bardzo ściśle ograniczonej grupy osób, np. członków jakiegoś towarzystwa naukowego. Warunkiem przyjęcia do tego rodzaju grupy będzie oczywiście członkostwo w danym towarzystwie.

Przyjmijmy zatem, że zapisaliśmy się do grupy Liver Transplant, i wejdźmy na tę stronę (ryc. 1). Zobaczymy wiele ostatnio toczonych dyskusji. Są to zarówno spory dotyczące gorących zagadnień związanych z tematyką przeszczepień wątroby, jak też prośby o pomoc w konkretnej sytuacji klinicznej. Jest to być może największa zaleta portalu Linkedln — za jego pomocą możemy w ciągu kilku godzin otrzymać specjalistyczne konsultacje dotyczące problematycznej sytuacji klinicznej. Co więcej, w przeciwieństwie do anonimowego w olbrzymiej mierze internetu możemy w kilka sekund dowiedzieć się, kto jest osobą udzielającą na dany temat rad oraz jakim doświadczeniem dysponuje. Mało tego: można sprawdzić, czy mamy wspólnych znajomych zajmujących się tą samą tematyką, oraz wreszcie poprosić o więcej rad już bezpośrednio, bez korzystania ze strony grupy dyskusyjnej (wysyłając wiadomość w obrębie Linkedln lub sprawdzając 


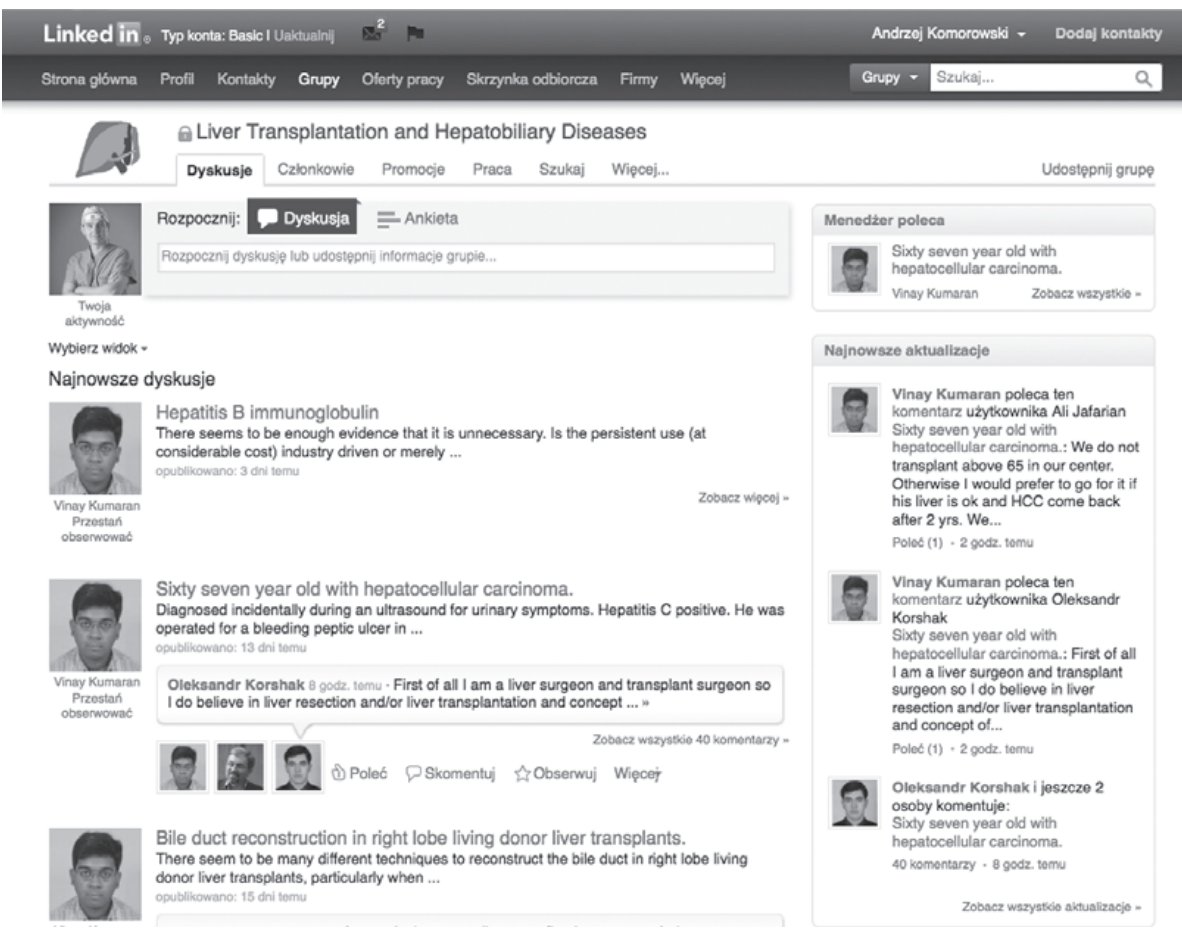

Rycina 1. Strona dyskusji w grupie „Liver Transplantation and Hepatobiliary Diseases"

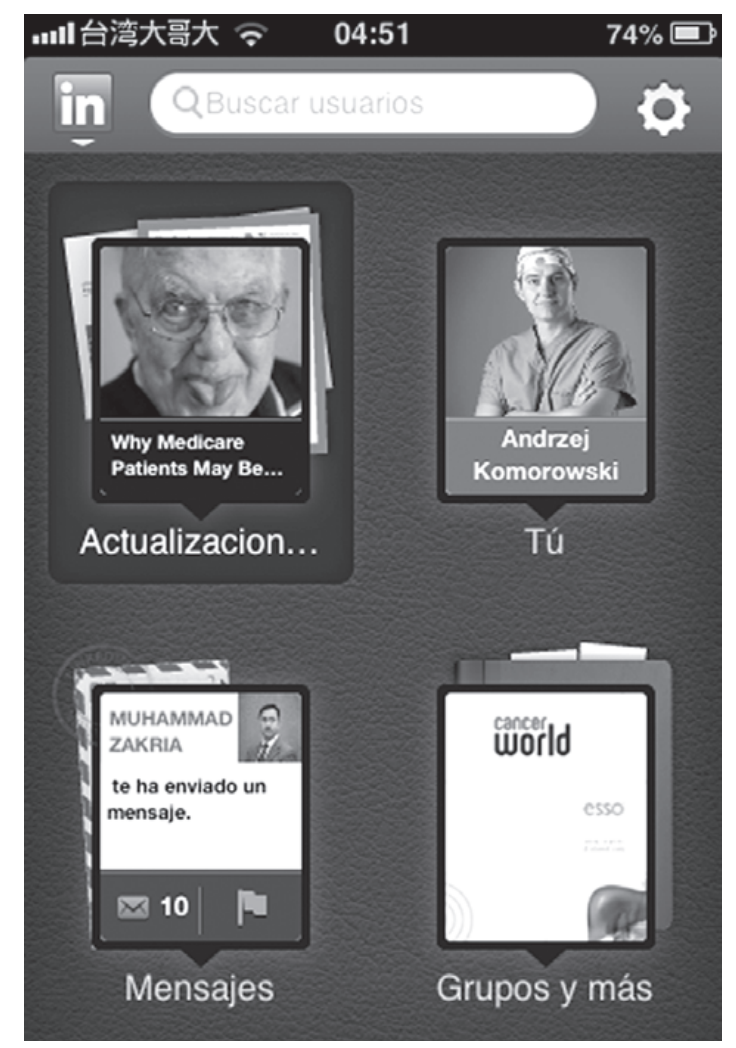

Rycina 2. Strona główna portalu na urządzeniu mobilnym (smartfonie) w profilu danej osoby jej adres e-mail i korzystając z niego). Posiadanie sieci kontaktów zawodowych w portalu Linkedln może oddać również nieocenione usługi podczas organizacji kongresów, spotkań naukowych, planowania badań wieloośrodkowych oraz pisania monografii. Jest to doskonałe narzędzie do znajdowania współpracowników z innych ośrodków oraz informowania się nawzajem o ważnych wydarzeniach naukowych.

Co ważne, portal Linkedln jest dostępny zarówno w wersji tradycyjnej, przeznaczonej na komputery, jak i w wersji na urządzenia mobilne. Wystarczy w sposób opisany na łamach poprzednich numerów „Nowotworów” zainstalować na swoim telefonie lub innym urządzeniu mobilnym aplikację Linkedln i rozpocząć korzystanie z jej możliwości (ryc. 2).Zawartość portalu w naszym telefonie, tablecie oraz dowolnym komputerze z którego wchodzimy na stronę LinkedIn będzie automatycznie aktualizowana. Oznacza to, że zmiany dokonane przez nas w tablecie będą natychmiast widoczne zarówno w naszym telefonie, komputerze, jak też w urządzeniach wszystkich innych użytkownikow, którzy oglądają nasz profil.

\section{Dr n. med. Andrzej L. Komorowski}

Liver Transplant Program, Department of Surgery, Chang Gung Memorial Hospital-Kaohsiung Medical Center, Chang Gung University College of Medicine, Kaohsiung, Tajwan e-mail:z5komoro@cyf-kr.edu.pl 